\title{
THE SALT AND WATER METABOLISM OF ADRENAL INSUFFICIENCY AND PARTIAL STARVATION IN RATS ${ }^{1}$
}

\author{
By MITCHELL I. RUBIN AND ELIZABETH T. KRICK \\ (From the University of Pennsylvania, School of Medicine, Department of Pediatrics, and the \\ Children's Hospital of Philadelphia, Philadelphia)
}

(Received for publication July 1, 1936)

All recent studies on the salt balance in adrenal insufficiency, both in the experimental animal and in Addison's disease, have shown that during this state sodium and chlorine are lost from the body $(1,2,3,4,5)$. Regarding the potassium balance a difference of opinion has been expressed. Some observers have stressed a retention of potassium $(3,4)$, while our studies $(5)$ demonstrated a loss of this salt. A possible explanation of this discrepancy may be found in the fact that the potassium balance is dependent to a great extent upon the food and water consumption during adrenal insufficiency, and that our rats show signs of anorexia earlier than is seen in the larger animals used by other workers. The present study was undertaken to demonstrate the effect of changes in the food consumption on the electrolytes and nitrogen balances of adrenalectomized rats.

Anorexia is an early symptom of insufficiency in the adrenalectomized rat. On the first day that sodium was added to the diet of the animals in adrenal insufficiency, the food intake returned to its original level, making it impossible to determine how much of the improvement in the salt balance was due to the added sodium and how much was due to the increased food consumption. For this reason it was found necessary, in an effort to evaluate the dietary factor, to conduct on normal nonadrenalectomized rats an experiment to show the influence on the salt and nitrogen balances of similar degrees of food restriction.

\section{PROCEDURES}

The animals used in these experiments were young white rats of the Wistar strain with an average weight of approximately 75 to 150 grams at the onset of the study. Bilateral adrenalectomy was done in one stage. The operations were performed under light ether anesthesia, the

1 Aided by a grant from the Faculty Research Committee of the University of Pennsylvania. complete procedure taking only a few minutes. The animals evidenced no immediate ill effects from the operation and were active after a few moments.

The diet employed throughout was Colony Breeder's Diet with the following composition:

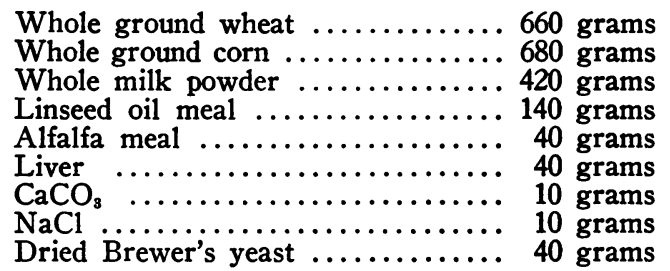

Two solutions were used in the treatment of rats during insufficiency.

(1) 0.9 per cent $\mathrm{NaCl}$ solution

(2) Salt mixture solution .7 per cent $\mathrm{NaCl}$ .0329 per cent $\mathrm{CaCl}_{2}$ .0350 per cent $\mathrm{KCl}$

.0150 per cent $\mathrm{MgCl}_{2} .6 \mathrm{H}_{2} \mathrm{O}$

Gamble metabolism cages were used for this study. In the majority of the adrenalectomy experiments the animals were studied in pairs, so as to increase the amount of material collected for study. In the undernutrition experiments, with the exception of Experiments $\mathrm{XI}$ and XII, only one rat was placed in each metabolism cage. This was necessary to make sure that each rat obtained the specified amount of food. In Experiments XI and XII glass partitions were placed in the cages separating the rats so that the individual rats obtained their allotted amounts of food.

A preservative was added to the urine and stool collecting receptacles. After completion of the study period, the cages and collecting apparatus were washed with glacial acetic acid and distilled water. Washings and urine collections were made up to volume for analyses. The stools and diet, before ashing, were finely powdered and dried.

\section{Wet ashing}

Approximately one half the total volume of the urine collected was evaporated in quartz crucibles and digested with concentrated nitric acid under quartz covers on the steam bath for eighty hours or until the solution was clear. It was evaporated again to dryness, taken up in distilled water, and left on the steam bath another day so as to drive off nitric oxide. Ashing of the stools and diet required more prolonged digestion. 


\section{METHODS}

Calcium was determined by the Tisdall and Kramer method (6), with the exception that 3 cc. of 15 per cent ammonium chloride were added to the ash solution to prevent precipitation of magnesium. For magnesium determinations the Greenberg and Mackey method (7) was used, and for sodium the Butler and Tuthill method (8). Potassium analysis was performed with the use of sodium cobaltinitrite solution prepared fresh each day from the dry powder. Care was taken that the cobaltinitrite precipitate was completely changed to the oxide both in filter tube and in beaker by thorough ashing (9). Phosphorus was determined by the Fiske-Subbarow method (10), and chlorine by the modified Volhard-Harvey method (11) for urine, and by the Sunderman and Williams method (12) for stool and diet. Nitrogen was determined by the macro-Kjeldahl method (13).

\section{RESULTS}

\section{A. Adrenal insufficiency}

It has been adequately demonstrated that bilateral adrenalectomy in certain strains of rats is followed in most instances by symptoms of adrenal insufficiency. It has also been shown in those strains of rats which do not become insufficient after the operation that there exists accessory adrenal cortical tissue. With the Wistar strain of rats we have been able to produce insufficiency in 80 per cent of the bilaterally adrenalectomized animals. In each instance where symptoms of insufficiency failed to develop after the operation additional adrenal tissue was found at autopsy.

The earliest signs of insufficiency were loss of weight with a coincident decrease in consumption of food and water. The level of the food intake did not parallel the level of the water intake. The food consumption fell immediately after adrenalectomy to a lowered level, where it remained more or less constant until it dropped sharply prior to death. The water intake was also decreased but not to such a great extent, the animal during adrenal insufficiency drinking more water per gram of food eaten than he did prior to adrenalectomy. In a previous publication (5) we reported that the urinary output decreased during adrenal insufficiency. However, since adopting the procedure of starting the postoperative balance studies immediately after operation, it was demonstrated (as was previously noted by Loeb and his coworkers) (3), that a temporary diuresis occurred during this early period. The diuresis persisted during the first thirty-six to forty-eight hours, after which the urinary output rapidly diminished as insufficiency, with its decreased water and food consumption, progressed. About seven days after the operation the animals developed progressive inactivity and weakness. Death in most instances occurred within ten to twenty days after adrenalectomy.

The severe weakness and the inactivity so striking in the rats with adrenal insufficiency were not present in the normal rats on the same level of decreased food consumption. The rats in the partial starvation experiments were very active throughout.

In the present investigation, balance studies on both bilaterally adrenalectomized rats and normal rats on varying degrees of underfeeding were made for calcium, magnesium, sodium, potassium, chlorine, phosphorus, and nitrogen.

In each instance following adrenalectomy, as shown in Table I, Experiments 1 to 10 (early postoperative periods), there occurred a marked decrease in the body retention of all the elements studied, progressing in most cases to a negative balance. The averages for the salt balances in the early postoperative periods show that the animals were in a negative balance for all the elements investigated except nitrogen, which was positive. The positive retention of this latter element, however, was less than one-tenth the magnitude of the normal nitrogen retention. Table I further demonstrates that in those instances where the nitrogen balance was negative the food consumption following adrenalectomy had dropped to a much smaller percentage of the normal than it did in those animals where the nitrogen balance was positive. In the late postoperative periods the balances were essentially similar to the early postoperative periods. The large negative balance for sodium in Experiment 4 is due to the fact that the animals in the previous period had been on salt therapy and were excreting at this time the large amount of sodium ingested in the previous period. The smaller negative potassium balance in this late postoperative period as compared to the earlier period might depend on failure of the kidney to excrete the potassium-the impaired renal function being in part dependent upon the dehydration. These observations differ from those of other workers 
TABLE I

Adrenalectomy experiments †

\begin{tabular}{|c|c|c|c|c|c|c|c|c|c|c|c|c|c|}
\hline & \multirow{2}{*}{$\begin{array}{c}\text { Experi- } \\
\text { ment } \\
\text { num- } \\
\text { ber }\end{array}$} & \multirow{2}{*}{$\underset{\text { ber }}{\text { Rat }}$} & \multirow{2}{*}{$\underset{\text { tion }}{\text { Dura- }}$} & \multirow{2}{*}{$\begin{array}{l}\text { Water } \\
\text { intake }\end{array}$} & \multirow{2}{*}{$\begin{array}{c}\text { Food } \\
\text { intake }\end{array}$} & \multirow{2}{*}{$\begin{array}{l}\text { Urine } \\
\text { output }\end{array}$} & \multicolumn{7}{|c|}{ Retentions } \\
\hline & & & & & & & $\mathrm{Ca}$ & Mg & $\mathrm{Na}$ & $\mathbf{K}$ & $\mathbf{P}$ & $\mathrm{Cl}$ & $\mathbf{N}$ \\
\hline $\begin{array}{l}\text { Control } \\
\text { periods }\end{array}$ & $\begin{array}{r}1 \\
2 \\
3 \\
4 \\
7 \\
10\end{array}$ & $\begin{array}{c}3,4 \\
5,6 \\
7,8 \\
15,16 \\
29,30 \\
70,71\end{array}$ & $\begin{array}{c}\text { days } \\
4 \\
5 \\
5 \\
6 \\
7 \\
3\end{array}$ & $\begin{array}{c}c c . \\
19.2 \\
21.7 \\
20.8 \\
16.2 \\
22.3 \\
13.7\end{array}$ & $\begin{array}{c}\text { grams } \\
16.6 \\
13.5 \\
13.3 \\
11.0 \\
9.85 \\
14.4\end{array}$ & $\begin{array}{l}c c . \\
8.5 \\
7.0 \\
4.0 \\
7.3 \\
3.8\end{array}$ & $\begin{array}{l}\text { mgm. } \\
+41.3 \\
+18.9 \\
+20.7 \\
+24.2 \\
+40.1 \\
+26.4\end{array}$ & $\begin{array}{r}m g m . \\
+3.2 \\
+0.4 \\
+0.1 \\
+4.1 \\
0.0 \\
+8.0\end{array}$ & $\begin{array}{r}\text { mgm. } \\
+28.0 \\
+5.5 \\
+4.7 \\
+1.2 \\
+13.8 \\
+1.6\end{array}$ & $\begin{array}{r}m g m . \\
+48.0 \\
+4.9 \\
+0.6 \\
+0.3 \\
+12.0 \\
+17.1\end{array}$ & $\begin{array}{l}\text { mgm. } \\
+18.1 \\
+13.4 \\
+12.6 \\
+11.4 \\
+17.4 \\
+6.5\end{array}$ & $\begin{array}{l}m g m . \\
-1.5 \\
+12.3 \\
+10.3 \\
+4.1 \\
+5.7 \\
+15.9\end{array}$ & $\begin{array}{r}\text { mgm. } \\
+135.8 \\
+66.7 \\
+73.4 \\
+122.8 \\
+141.9 \\
+148.5\end{array}$ \\
\hline \multicolumn{4}{|c|}{ Averages } & 18.9 & 13.1 & 5.1 & +28.6 & +2.6 & +9.0 & +13.8 & +13.2 & +2.5 & +115.0 \\
\hline $\begin{array}{l}\text { Early postopera- } \\
\text { tive periods }\end{array}$ & $\begin{array}{r}1 \\
2 \\
3 \\
4 \\
5 \\
6 \\
7 \\
8 \\
9 \\
10\end{array}$ & $\begin{array}{c}3,4 \\
5 \\
8 \\
15,16 \\
23,24 \\
25,26 \\
29,30 \\
39,40 \\
41,42 \\
70,71\end{array}$ & $\begin{array}{c}\text { 2nd-12th } \\
\text { 1st-9th } \\
\text { 1st-9th } \\
\text { 1st-6th } \\
\text { 4th-7th } \\
\text { 4th-7th } \\
\text { 2nd-10th } \\
\text { 2nd-6th } \\
\text { 4th-8th } \\
\text { 1st-3rd }\end{array}$ & $\begin{array}{r}16.2 \\
19.0 \\
10.6 \\
6.3 \\
7.0 \\
5.0 \\
17.5 \\
5.0 \\
12.0 \\
16.6\end{array}$ & $\begin{array}{l}8.2 \\
6.2 \\
3.3 \\
1.5 \\
3.8 \\
3.6 \\
7.2 \\
0.7 \\
3.0 \\
6.5\end{array}$ & $\begin{array}{r}8.0 \\
12.5 \\
4.6 \\
4.8 \\
3.0 \\
3.6 \\
6.5 \\
3.0 \\
7.2 \\
10.5\end{array}$ & $\begin{array}{r}+9.9 \\
+3.2 \\
+1.0 \\
+0.0 \\
+7.0 \\
+9.3 \\
+17.3 \\
+39.2 \\
0.0 \\
-32.6\end{array}$ & $\begin{array}{l}-0.6 \\
-0.8 \\
-1.2 \\
-1.0 \\
+1.0 \\
+1.9 \\
-4.3 \\
-5.9 \\
-6.5 \\
-2.3\end{array}$ & $\begin{array}{l} \pm 3.0 \\
\pm 2.2 \\
=2.8 \\
=7.8 \\
=0.9 \\
\pm 0.7 \\
=4.0 \\
=8.0 \\
=7.0 \\
-17.8\end{array}$ & $\begin{array}{l}-1.0 \\
-21.7 \\
-10.3 \\
=14.8 \\
=24.0 \\
=13.0 \\
=5.9 \\
=19.1 \\
=10.3 \\
-26.9\end{array}$ & $\begin{array}{l}-0.7 \\
0.0 \\
=3.4 \\
=6.0 \\
=0.1 \\
+0.5 \\
\pm 8.0 \\
\pm 8.1 \\
=2.4 \\
-18.6\end{array}$ & $\begin{array}{l}+3.2 \\
+1.0 \\
+0.8 \\
\pm 9.4 \\
=3.9 \\
=2.4 \\
=3.4 \\
+6.4 \\
+0.9 \\
-24.5\end{array}$ & $\begin{array}{l}+66.5 \\
\pm \quad 1.7 \\
=37.1 \\
=23.8 \\
+19.1 \\
+13.2 \\
+101.5 \\
=40.0 \\
=\quad 0.9 \\
+\quad 8.1\end{array}$ \\
\hline \multicolumn{4}{|c|}{ Averages } & 11.5 & 4.4 & 6.4 & -2.6 & -2.0 & -4.7 & -14.8 & -3.2 & -4.6 & +10.5 \\
\hline $\begin{array}{l}\text { Late } \\
\text { postoperative } \\
\text { periods }\end{array}$ & $\begin{array}{r}1 \\
4 \\
10\end{array}$ & $\begin{array}{c}3,4 \\
15,16 \\
70,71\end{array}$ & $\begin{array}{l}\text { 12th-18th } \\
9 \text { th-13th } \\
\text { 10th-13th }\end{array}$ & $\begin{array}{r}11.3 \\
15.8 \\
7.5\end{array}$ & $\begin{array}{l}4.2 \\
2.7 \\
4.2\end{array}$ & $\begin{array}{l}7.9 \\
3.1\end{array}$ & $\begin{array}{l}-3.8 \\
\overline{+} \\
+1.2\end{array}$ & $\begin{array}{l}-0.9 \\
-1.4 \\
+0.6\end{array}$ & $\begin{array}{l}-3.7 \\
=49.3 * \\
-1.2\end{array}$ & $\begin{array}{l}-9.0 \\
=10.1 \\
-1.9\end{array}$ & $\begin{array}{l}-6.0 \\
=2.8 \\
=4.9\end{array}$ & $\begin{array}{l}-4.3 \\
=10.1 \\
-9.1\end{array}$ & $\begin{array}{l}+3.2 \\
+\quad 2.5 \\
+\quad 19.1\end{array}$ \\
\hline \multicolumn{4}{|c|}{ Averages } & 11.5 & 3.7 & 5.5 & -2.1 & -0.4 & -18.1 & -7.0 & -4.6 & -7.8 & +8.3 \\
\hline 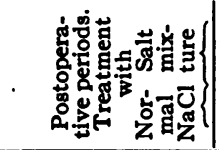 & $\begin{array}{l}4 \\
5 \\
6 \\
8 \\
9\end{array}$ & $\begin{array}{l}15,16 \\
23,24 \\
25,26 \\
39,40 \\
41,42\end{array}$ & $\begin{array}{l}\text { 6th-9th } \\
7 \mathrm{th}-15 \mathrm{th} \\
\text { 7th-15th } \\
\text { 7th-19th } \\
\text { 8th-14th }\end{array}$ & $\begin{array}{l}36.4 \\
37.2 \\
32.5 \\
40.0 \\
42.8\end{array}$ & $\begin{array}{r}7.4 \\
10.1 \\
8.2 \\
10.3 \\
9.7\end{array}$ & $\begin{array}{l}25.0 \\
21.6 \\
17.5 \\
18.0 \\
29.6\end{array}$ & $\begin{array}{l}+7.3 \\
+28.8 \\
+27.9 \\
+23.5 \\
+25.8\end{array}$ & $\begin{array}{l}+0.9 \\
+8.3 \\
+7.8 \\
-0.8 \\
+1.6\end{array}$ & $\begin{array}{r}+8.5 \\
+55.9 \\
+18.4 \\
+19.3 \\
+5.4\end{array}$ & $\begin{array}{r}-3.4 \\
+12.8 \\
+15.9 \\
+18.5 \\
+6.0\end{array}$ & $\begin{array}{r}+7.7 \\
+13.3 \\
+11.8 \\
+10.2 \\
+18.4\end{array}$ & $\begin{array}{l}+12.9 \\
+21.6 \\
+19.1 \\
+46.7 \\
+24.4\end{array}$ & $\begin{array}{l}+54.7 \\
+150.9 \\
+101.5 \\
+156.6 \\
+112.3\end{array}$ \\
\hline \multicolumn{4}{|c|}{ Averages } & 37.8 & 9.1 & 22.3 & +22.6 & +3.5 & +21.1 & +10.0 & +12.3 & +24.9 & +115.2 \\
\hline
\end{tabular}

* This value is large because these rats ingested large amounts of $\mathrm{NaCl}$ preceding this period.

$\dagger$ All values per rat per day.

who have maintained that sodium and chlorine alone are lost and that potassium is retained.

In Experiment 5, during the early postoperative period, the presence of only a slightly negative sodium balance, despite the presence of a large negative potassium balance, is probably due to the fact that the metabolic period was not begun until the fourth postoperative day, and since the large urinary output which usually occurs immediately after operation was not collected, the body may have been during this study period already depleted of the sodium available for excretion.

In the postoperative period of Experiment 7 where sodium, potassium, magnesium, and chlorine were the only elements in negative balance, one of the two animals in this pair did not have severe insufficiency during the postoperative meta- bolic period. However, the retentions of the other elements investigated were less in the postoperative period than in the normal period, and the average daily food consumption in the postoperative period was also lower than in the normal.

In Experiment 6 during the early postoperative period the animals had not shown evidence of severe adrenal insufficiency; nevertheless, the potassium and chlorine balances were negative.

\section{B. Partial starvation}

In the partial starvation experiments, XI through XXI (Table II), the amounts of food given to the normal rats paralled the food intake of the rats during adrenal insufficiency. During the first twenty-four hours following adrenalectomy the food consumption of rats falls to about 
TABLE II

Partial staroation experiments †

\begin{tabular}{|c|c|c|c|c|c|c|c|c|c|c|c|c|c|}
\hline & \multirow{2}{*}{$\begin{array}{c}\text { Experi- } \\
\text { ment } \\
\text { num- } \\
\text { ber }\end{array}$} & \multirow{2}{*}{$\mid \begin{array}{c}\text { Rat } \\
\text { number } \\
\text { ber }\end{array}$} & \multirow{2}{*}{$\underset{\text { tion }}{\text { Dura- }}$} & \multirow{2}{*}{$\begin{array}{l}\text { Water } \\
\text { intake }\end{array}$} & \multirow{2}{*}{$\begin{array}{l}\text { Food } \\
\text { intake }\end{array}$} & \multirow{2}{*}{$\begin{array}{l}\text { Urine } \\
\text { output }\end{array}$} & \multicolumn{7}{|c|}{ Retentions } \\
\hline & & & & & & & $\mathrm{Ca}$ & $\mathbf{M g}$ & $\mathrm{Na}$ & $\mathbf{K}$ & $\mathbf{P}$ & $\mathrm{Cl}$ & $\mathbf{N}$ \\
\hline Control periods & $\begin{array}{r}\text { XI } \\
\text { XII } \\
\text { XII } \\
\text { XIV } \\
\text { XV } \\
\text { XVI } \\
\text { XVII } \\
\text { XVIII } \\
\text { XIX } \\
\text { XX } \\
\text { XXI }\end{array}$ & $\begin{array}{c}76,77 \\
74,75 \\
102 \\
122 \\
123 \\
125 \\
163 \\
164 \\
165 \\
166 \\
167\end{array}$ & $\begin{array}{c}\text { days } \\
8 \\
11 \\
4 \\
4 \\
4 \\
4 \\
5 \\
5 \\
5 \\
5 \\
3\end{array}$ & $\begin{array}{l}c c . \\
7.0 \\
6.5 \\
13.5 \\
16.0 \\
18.0 \\
15.0 \\
13.0 \\
11.0 \\
14.0 \\
13.6 \\
21.0\end{array}$ & $\begin{array}{c}\text { grams } \\
5.8 \\
5.8 \\
9.6 \\
10.0 \\
13.6 \\
9.1 \\
10.5 \\
10.8 \\
7.6 \\
10.2 \\
12.7\end{array}$ & $\begin{array}{l}c c . \\
1.3 \\
0.9 \\
7.8 \\
5.8 \\
6.0 \\
8.2 \\
5.0 \\
2.6 \\
4.4 \\
3.4 \\
3.0\end{array}$ & $\begin{array}{r}m g m . \\
+21.7 \\
+16.6 \\
+19.5 \\
+22.7 \\
+42.2 \\
+24.1 \\
+37.1 \\
+32.7 \\
+30.9 \\
+38.0 \\
+32.9\end{array}$ & $\begin{array}{c}m g m . \\
-3.2 \\
+1.6 \\
+20.4 \\
-15.9 \\
=2.5 \\
\mp 7.6 \\
+4.7 \\
+1.2 \\
+5.9 \\
+3.0 \\
+6.3\end{array}$ & $\begin{array}{r}m g m . \\
+3.1 \\
+4.8 \\
+3.9 \\
+7.8 \\
+3.9 \\
+2.9 \\
+9.0 \\
+9.0 \\
+7.2 \\
+5.1 \\
+1.6 \\
+3.0\end{array}$ & $\begin{array}{r}m g m . \\
+15.4 \\
+21.9 \\
+11.8 \\
+6.7 \\
+10.4 \\
-33.7 \\
+28.0 \\
+20.8 \\
+19.3 \\
+21.3 \\
+9.0\end{array}$ & $\begin{array}{r}m g m . \\
+23.6 \\
+23.8 \\
+5.2 \\
+6.4 \\
+19.1 \\
+8.2 \\
+18.3 \\
+30.0 \\
+14.8 \\
+18.0 \\
+10.9\end{array}$ & $\begin{array}{r}m g m . \\
+3.1 \\
+3.9 \\
+10.7 \\
+11.5 \\
+14.2 \\
+8.6 \\
+\quad 4.8 \\
\pm \quad 5.6 \\
\pm 0.6 \\
\pm 2.6 \\
-25.2\end{array}$ & $\begin{array}{r}m g m . \\
+57.3 \\
+\quad 68.4 \\
+27.4 \\
+16.8 \\
+166.7 \\
+30.4 \\
+310.5 \\
+11.8 \\
+70.4 \\
+100.3 \\
+99.1\end{array}$ \\
\hline \multicolumn{4}{|c|}{ Averages } & 13.5 & 9.7 & 4.4 & +28.1 & -2.4 & +4.7 & +12.5 & +16.2 & +3.6 & +91.5 \\
\hline $\begin{array}{l}\text { Partial starvation } \\
\text { Early perio }\end{array}$ & $\begin{array}{r}\text { XI } \\
\text { XII } \\
\text { XIII } \\
\text { XIV } \\
\text { XV } \\
\text { XVI }\end{array}$ & $\begin{array}{c}76,77 \\
74,75 \\
102 \\
122 \\
123 \\
125\end{array}$ & $\begin{array}{r}13 \\
9 \\
4 \\
4 \\
4 \\
4\end{array}$ & $\begin{array}{r}7.8 \\
4.4 \\
17.5 \\
17.5 \\
15.0 \\
15.0\end{array}$ & $\begin{array}{l}2.5 \\
4.7 \\
5.0 \\
5.0 \\
7.0 \\
5.0\end{array}$ & $\begin{array}{r}1.0 \\
0.6 \\
11.5 \\
10.2 \\
10.0 \\
11.2\end{array}$ & $\begin{array}{r}+2.8 \\
+15.1 \\
+1.6 \\
+5.3 \\
+8.8 \\
+14.2\end{array}$ & $\begin{array}{r}-0.6 \\
\pm \quad 16 \\
\pm 4.5 \\
=5.4 \\
=4.8 \\
-4.5\end{array}$ & $\begin{array}{l}+0.2 \\
+0.1 \\
+0.9 \\
+0.3 \\
+0.8 \\
+0.1\end{array}$ & $\begin{array}{r}+4.7 \\
+8.6 \\
+5.5 \\
-4.8 \\
-11.8 \\
-5.8\end{array}$ & $\begin{array}{r}+0.3 \\
=4.9 \\
=3.5 \\
=1.9 \\
=1.6\end{array}$ & $\begin{array}{r}+1.3 \\
+3.7 \\
+1.8 \\
+5.8 \\
+4.3 \\
+3.5\end{array}$ & $\begin{array}{r}+1.3 \\
+41.3 \\
\pm \quad 30.5 \\
+1.4 \\
+59.7 \\
\pm \quad 15.8\end{array}$ \\
\hline \multicolumn{4}{|c|}{ Averages } & 12.9 & 4.9 & 7.4 & +7.9 & -3.0 & +0.3 & -2.4 & -2.1 & +3.4 & +57.5 \\
\hline $\begin{array}{l}\text { Partial starvation (food). } \\
\text { Late periods }\end{array}$ & $\begin{array}{l}\text { XI } \\
\text { XIII } \\
\text { XII } \\
\text { XV } \\
\text { XVI }\end{array}$ & $\begin{array}{c}76.77 \\
74,75 \\
102 \\
122 \\
123 \\
125\end{array}$ & $\begin{array}{r}8 \\
11 \\
5 \\
5 \\
5 \\
5\end{array}$ & $\begin{array}{l}6.3 \\
4.6 \\
8.4 \\
7.0 \\
8.0 \\
5.0\end{array}$ & $\begin{array}{l}1.3 \\
1.2 \\
2.5 \\
2.5 \\
3.5 \\
2.5\end{array}$ & $\begin{array}{l}4.3 \\
0.9 \\
4.4 \\
4.0 \\
5.0 \\
3.2\end{array}$ & $\begin{array}{l}+1.1 \\
\pm 1.0 \\
\pm \quad 4.8 \\
+1.6 \\
+7.2 \\
+3.9\end{array}$ & $\begin{array}{l}-0.5 \\
=11.0 \\
=0.4 \\
\pm 0.3 \\
=0.7 \\
-0.9\end{array}$ & $\begin{array}{l}-4.5 \\
-0.8 \\
-0.4 \\
-2.0 \\
-0.6 \\
-2.3\end{array}$ & $\begin{array}{r}-9.4 \\
=1.6 \\
=2.3 \\
-10.2 \\
+5.5 \\
-3.1\end{array}$ & $\begin{array}{r}-3.6 \\
+\quad 3.1 \\
\pm \quad 0.5 \\
\pm \quad 2.1 \\
=3.6 \\
-3.7\end{array}$ & $\begin{array}{r}-0.9 \\
+1.3 \\
\pm 4.8 \\
\pm 0.8 \\
+1.9 \\
+3.6\end{array}$ & $\begin{array}{r}-40.5 \\
=21.3 \\
=10.5 \\
+\quad 1.1 \\
\pm \quad 16.6 \\
-43.6\end{array}$ \\
\hline \multicolumn{4}{|c|}{ Averages } & 6.5 & 2.3 & 3.6 & +2.7 & -0.5 & -1.8 & -3.5 & -2.6 & +1.9 & -16.4 \\
\hline $\begin{array}{l}\text { Partial starvation } \\
\text { (water and food). } \\
\text { Early periods }\end{array}$ & $\begin{array}{r}\text { XVII } \\
\text { XVIII } \\
\text { XIX } \\
\text { Xx } \\
\text { XXI }\end{array}$ & $\begin{array}{l}163 \\
164 \\
165 \\
166 \\
167\end{array}$ & $\begin{array}{l}5 \\
5 \\
5 \\
5 \\
5\end{array}$ & $\begin{array}{l}6.0 \\
6.0 \\
6.0 \\
6.0 \\
6.0\end{array}$ & $\begin{array}{l}5.5 \\
5.5 \\
4.0 \\
5.5 \\
6.0\end{array}$ & $\begin{array}{l}2.4 \\
1.6 \\
1.6 \\
1.6 \\
1.8\end{array}$ & $\begin{array}{l}+24.0 \\
+19.8 \\
+11.1 \\
+16.1 \\
+18.1\end{array}$ & $\begin{array}{r}0.0 \\
-\quad 0.6 \\
+\quad 0.6 \\
+2.9 \\
+3.9\end{array}$ & $\begin{array}{r}-0.8 \\
0.0 \\
+3.1 \\
-0.7 \\
+0.3\end{array}$ & $\begin{array}{r}+3.2 \\
+\quad 1.3 \\
+9.4 \\
+7.1 \\
+9.4\end{array}$ & $\begin{array}{r}+2.6 \\
+4.2 \\
+3.4 \\
+\quad 4.5 \\
+5.0\end{array}$ & $\begin{array}{r}-0.5 \\
-\quad 4.2 \\
+2.7 \\
+0.5 \\
+\quad 1.9\end{array}$ & $\begin{array}{r}+\quad 18.7 \\
+23.5 \\
+\quad 15.3 \\
+\quad 15.7 \\
+36.4\end{array}$ \\
\hline \multicolumn{4}{|c|}{ Averages } & 6.0 & 5.3 & 1.8 & +17.8 & +1.4 & +0.5 & +5.6 & +3.9 & +0.08 & +21.9 \\
\hline $\begin{array}{l}\text { Partial starvation } \\
\text { (water and food). } \\
\text { Late periods }\end{array}$ & $\begin{array}{r}\text { XVII } \\
\text { xVIII } \\
\text { XIX } \\
\text { Xxx } \\
\text { Xxi }\end{array}$ & $\begin{array}{l}163 \\
164 \\
165 \\
166 \\
167\end{array}$ & $\begin{array}{l}\mathbf{5} \\
\mathbf{5} \\
\mathbf{5} \\
\mathbf{5} \\
\mathbf{5}\end{array}$ & $\begin{array}{l}3.0 \\
3.0 \\
2.0 \\
3.0 \\
3.0\end{array}$ & $\begin{array}{l}3.0 \\
3.0 \\
2.0 \\
3.0 \\
3.0\end{array}$ & $\begin{array}{l}1.2 \\
1.0 \\
1.2 \\
1.0 \\
1.4\end{array}$ & $\begin{array}{r}+6.7 \\
+\quad 0.9 \\
+5.6 \\
+8.1 \\
+6.8\end{array}$ & $\begin{array}{l}=0.4 \\
=0.6 \\
=2.8 \\
=1.8\end{array}$ & $\begin{array}{l}-2.4 \\
-0.1 \\
-3.4 \\
-5.3 \\
-3.6\end{array}$ & $\begin{array}{l}-18.8 \\
-15.5 \\
=9.0 \\
=3.5 \\
-17.3\end{array}$ & $\begin{array}{l}-3.0 \\
=22.8 \\
=4.9 \\
=2.9 \\
-2.4\end{array}$ & $\begin{array}{l}=4.5 \\
=2.5 \\
=5.3 \\
=0.1 \\
=3.8\end{array}$ & $\begin{aligned}- & 50.0 \\
= & 29.4 \\
= & 20.0 \\
& 25.9 \\
- & 35.9\end{aligned}$ \\
\hline \multicolumn{4}{|c|}{ Averages } & 2.8 & 2.8 & 1.2 & +5.6 & -1.4 & -2.9 & -12.8 & -3.0 & -3.2 & -32.2 \\
\hline
\end{tabular}

$\dagger$ All values per rat per day.

one-half the normal amount. After several days, during the stage of more advanced insufficiency, the food intake drops again to one-fourth the normal, and then just prior to death, food is entirely refused. In Experiments XVII through $\mathrm{XXI}$, where the water as well as the food intake was restricted, the balances were similar to those where food alone was restricted, except for the late period of water and food restriction. Here, with the marked decrease in the water intake, the negative potassium and nitrogen balances were greater, demonstrating more tissue destruction. In Experiments XI and XII data are given from a different investigation on undernutrition where the food restrictions of normal rats paralled the decreasing food consumption of animals in vitamin $B_{1}$ deficiency. In these experiments water was allowed ad libitum.

The results of these underfeeding experiments, as given in Table II, demonstrate that during undernutrition the changes in the retentions of the elements investigated proceed in a similar direc- 
tion to those of adrenal insufficiency, but are of a lesser magnitude. In the adrenal insufficiency experiments the average daily balance during the control periods for sodium was +9 mgm., for potassium $+13.8 \mathrm{mgm}$. During insufficiency when the average food consumption was about one-third normal, the average daily balance of sodium was $-4.7 \mathrm{mgm}$., and of potassium -14.8 mgm. In the partial starvation experiments the average daily balance during the control period was $+4.7 \mathrm{mgm}$. for sodium and $+12.5 \mathrm{mgm}$. for potassium, while during the period where the food intake was one-fourth normal, the average daily sodium balance was $-1.8 \mathrm{mgm}$., and the average daily potassium balance was $-3.5 \mathrm{mgm}$. The chlorine losses were also greater during adrenal insufficiency than during partial starvation. The losses of calcium, magnesium, and phosphorus during the two situations are essentially comparable. The differences in the average nitrogen retentions of these two experiments, as given in Tables I and II, might depend on the fact that during the early postoperative periods some of the animals did not develop a severe enough insufficiency to have a marked anorexia and a negative nitrogen balance as in Experiment 7. A false average value for the adrenalectomized rats would therefore be obtained. In the late postoperative periods kidney failure might prevent the nitrogen excretion. It would seem, therefore, that while the decreased food consumption during advanced adrenal insufficiency is in a large part responsible for the altered electrolyte and nitrogen balances, the adrenal gland per se partly influences the balances of those electrolytes which are associated with the water of the body, namely: sodium, potassium, and chlorine.

\section{Treatment with salt solutions}

Doubt has been expressed by some workers as to whether completely adrenalectomized rats will respond to salt therapy. The degree of insufficiency obtained by the type of operation performed in our laboratory is fatal to the animals in 80 per cent of the untreated cases. Nevertheless, salt therapy is successful in rats with this degree of insufficiency. Table I, Experiments 4, $5,6,8$ and 9 , shows the beneficial effect of salt therapy on the electrolyte and nitrogen balances following adrenalectomy. In each instance following salt therapy there was a return of the electrolyte and nitrogen balances to normal. This therapy, it is to be stressed, was always associated with an immediate return of the appetite. It should be pointed out here that salt therapy may be unsuccessful in restoring rats when adrenalectomy is performed at a very early age.

The weight curves of the adrenalectomized animals on both the salt mixture solution and the normal saline solution demonstrate that the growth of these animals is not as great as that of normal controls. We have, however, kept completely adrenalectomized animals in apparently good health for over ten months by giving them either one of these two salt solutions. On the other hand, animals treated with either of these salt solutions eventually die in insufficiency, demonstrating that the salts given do not completely restore the body equilibrium. This suggests that other body mechanisms disturbed by adrenalectomy in rats are not restored when the animals are given these additional salts. This is in keeping with clinical experience in the use of sodium chloride in Addison's disease.

\section{Water balance}

Since adrenalectomized animals treated by the addition of salt to their drinking water consume large amounts of this fluid, the question arises whether these animals drink abnormally large quantities of salt solution in order to obtain excess water or the added salt. That adrenalectomized animals soon refuse to drink distilled water is good evidence, we believe, that additional salt is desired. In an effort to determine whether the actual amount of salt ingested was the important factor, we used varying concentrations of sodium chloride in the water. In one group of rats the average hourly consumption of fluid per rat on the 0.65 per cent sodium chloride solution was $3.6 \mathrm{cc}$., and on the 1.4 per cent solution it was $1.4 \mathrm{cc}$. It is interesting to find that the rats on the weaker solution drank enough of it to keep their salt intake at a level comparable with that of the rats on the more concentrated salt solution. Adrenalectomized rats given the added salt in their diet but deprived of water died much more quickly than normal rats deprived of water. 
It is interesting to note that the animals during adrenal insufficiency drank more water per gram of food eaten than during their normal control period. Only rarely did the normal control animals drink more than $2 \mathrm{cc}$. of water per gram of food eaten. Usually the water to food ratio of normal rats was between .9 and 1.5. During insufficiency rarely did the ratio fall below 2.5 . It occasionally rose to 4 . It is possible that the increased consumption of water during adrenal insufficiency is an effort on the part of the animal to prevent the excessive dehydration which would result from the diuretic effect of the increased urea and potassium in the body fluids coming from cellular breakdown. It would appear from these data that, in addition to an excess of salt, an excess of water is needed to maintain health in these animals. The water to food ratio during partial starvation is similar to that of adrenal insufficiency. Here, too, the tissue breakdown occurring during undernutrition would produce an increased amount of urea and potassium for excretion.

Figure 1 compares the weight curves of normal and adrenalectomized animals on an unrestricted diet when salt (sodium chloride) is added and then removed from the drinking water. It is interesting that in the normal rats no weight loss

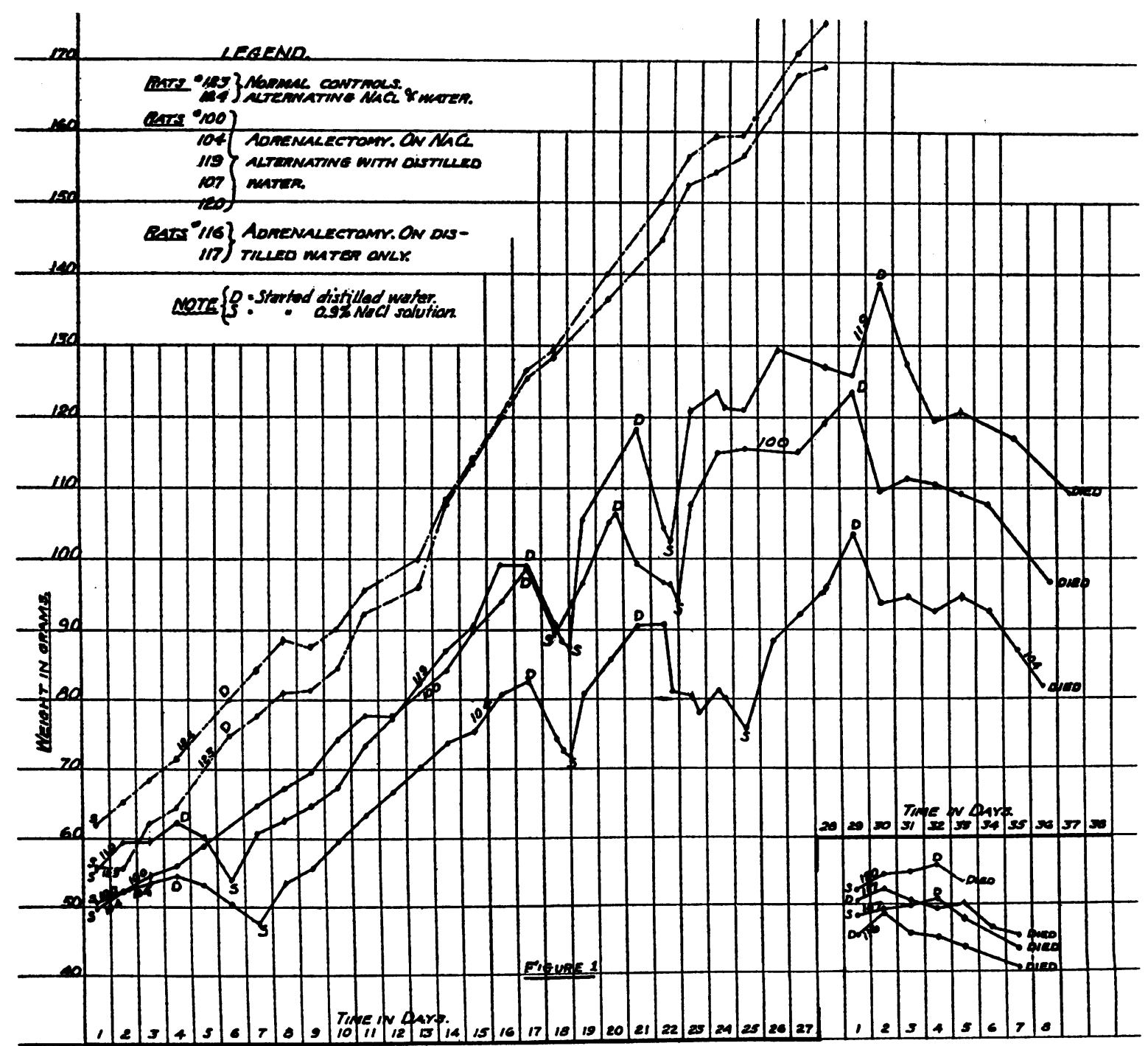

Fig. 1. Experiment 50. Normal and Adrenalectomized Rats on Treatment with 0.9 Per Cent NaCi. 
occurred when the added salt was removed from the drinking water, demonstrating the ability of normal rats to regulate their salt retentions. We would have expected a sudden weight loss when salt was withdrawn from the drinking water of the normal rats if the previously added salt was being retained with water in the body. However, it is well known that the normal kidney can excrete a large excess of salt. The fact that the adrenalectomized animals, which were gaining weight while on the added salt, immediately lost weight when the salt was withdrawn, demonstrates that these adrenalectomized rats had not stored in the body any salt that might tide them over for even short periods of salt deprivation, and were unable to regulate their salt and water retentions. It is, however, apparent that adrenalectomized animals have not completely lost their power to regulate their salt and water balance when adequate amounts of these substances are administered.

When the figures for salt balances are. calculated so as to compare the milligrams of each element excreted to the grams of food consumed, it becomes obvious that during adrenal insufficiency the animal does not conserve its salts. For example, in Experiment 2, during the control period the animal excreted $2.2 \mathrm{mgm}$. calcium for each gram of food consumed, while during insufficiency, despite the lowered food intake, the animal excreted $3.2 \mathrm{mgm}$. calcium per gram of food consumed. For magnesium the figure for the control period is 1.4 against 1.6 for the insufficient period, and so with sodium where the figures are 2.2 as compared to 3.0. For potassium we have 5.1 to 9.1 ; for phosphorus 2.3 to 3.3 ; for chlorine 4.3 to 5.1 ; and for nitrogen 19.5 to 23.5. In each of the experiments this loss of salt economy during adrenal insufficiency is demonstrated. A similar lack of salt conservation has been found in normal rats which are partially starved. Thus, it is again demonstrated that the electrolyte changes occurring in the organism during adrenal insufficiency are influenced by the lowered food intake.

\section{DISCUSSION}

\section{Influence of food consumption on electrolyte and nitrogen metabolism}

The similarity of the altered electrolyte and nitrogen balances during partial starvation and during adrenal insufficiency indicates, as was suggested in our earlier paper (5), that the changes in electrolyte and nitrogen balance found during moderately advanced adrenal insufficiency are in a measure dependent upon the lowered food consumption after adrenalectomy. Harrop and his associates (14) have shown that the lowered blood sugar found during adrenal insufficiency in dogs is dependent upon the lowered food intake. However, it is apparent from our data that the lowered food intake is not the entire cause of the altered balances, for the reduced retentions of sodium, potassium, and chlorine during adrenal insufficiency are greater than those seen in similar degrees of undernutrition in normal rats. It thus seems clear that the adrenal gland itself has some influence on the retentions of those electrolytes associated with the body water. In agreement with this, Loeb, Harrop, and their coworkers (3, 4) have demonstrated alterations in the sodium balance prior to the appearance of anorexia. Regarding the calcium, magnesium, phosphorus, and nitrogen, the retentions of these elements in adrenal insufficiency parallel the amount of food consumed.

\section{Sodium metabolism}

Regarding the influence of the adrenal gland on the sodium metabolism, it would appear that with the removal of this gland the following sequence of events occurs. Initially there is a diuresis. Since the extracellular water is the most available, sodium, which is the chief electrolyte of this body fluid compartment, is the first salt to be excreted. As the store of extracellular water with its sodium is depleted, the intracellular water with its potassium is next drawn upon to keep up a falling circulating fluid volume. There seems to be no doubt that sodium is lost from the body during the dehydration of adrenal insufficiency. It is also true that during undernutrition sodium is lost, but to a lesser extent. Similarly, in many unrelated conditions which have dehydration as a factor in common, i.e., starvation (15), diabetic acidosis, diuresis $(16,17)$, and nephritis (18), sodium is lost from the body in large amounts, and the sodium and chlorine changes of the blood serum, where they have been investigated, are similar to the sodium and chlorine changes of the blood in adrenal insufficiency. From these facts 
alone it would appear that the sodium loss in adrenal insufficiency is not necessarily a specific function of the adrenal gland but is an accompaniment of dehydration. That during adrenal insufficiency the sodium concentration in the urine is increased despite the diuresis (3), demonstrating a loss of sodium in amounts above that expected from the water loss, does not ipso facto imply that sodium is selectively excreted. The extra water which should have been excreted by the kidney, if there had been simply a diuresis of extracellular water, may have been partly lost through the lungs or lost into the body cells. Darrow and Yannet (19) have shown that when there is a large loss of sodium from the extracellular water, in the redistribution of water, water enters the cells to reestablish an osmotic equilibrium. This must occur prior to the loss of potassium from the cells. The kidney in this case excretes a more concentrated sodium solution so as to permit the water retention. In a study by Kerpel-Fronius and Butler (17) where diuretin was administered to rabbits, they found that along with a marked diuresis, sodium and potassium were lost in large quantities. The blood sodium in these animals was found to be lowered to a degree comparable with that of adrenal insufficiency. In their Experiment 4, on the first diuretin day, the concentration of sodium in the urine was about twice that of the sodium concentration on the next day when diuretin was not used. This increased concentration of sodium in the urine with an increased urinary volume is similar to the findings of Loeb et al. (3) in adrenal insufficiency.

That the addition of sodium chloride to the intake during insufficiency restores the animal is again not indicative of a specific regulation of the sodium metabolism per se by the adrenal glands. It merely demonstrates that replacement of sodium is specific for sodium loss whether it is due to adrenal insufficiency, nephritis, or diarrhea. In all forms of shock due to dehydration sodium chloride solution aids greatly in restoration to normal. In the dehydration due to severe diarrhea in infancy, sodium chloride solution is beneficial.

The recent studies of Swingle and his associates (20) have demonstrated that with hormonal therapy during starvation clinical improvement in the adrenalectomized animal may occur prior to any change in the lowered blood sodium.

It is most likely that the beneficial effect of sodium when given in large amounts results from its ability, when the animal has access to water, to restore the depleted water of the blood and interstitial tissue which had been lost during the early diuresis. Finally, sodium replacement therapy has not completely restored the animal or the human in adrenal insufficiency. Several of our rats, more especially the very young, have died of insufficiency while on sodium.

\section{Potassium metabolism}

$A$ negative potassium balance was demonstrated in each instance during adrenal insufficiency in our rats. The negative balance for this element was greater than that found in similar degrees of partial starvation in the normal rat. However, when this partial starvation of food was associated with a forced reduction in the water intake, the negative potassium balances were comparable to those of adrenal insufficiency. In the former circumstance, the forced reduction of water most probably resulted in an increased amount of tissue destruction, thus liberating more potassium for excretion.

In many instances during insufficiency the potassium losses were four or five times greater than those which should have been expected if potassium were lost only on cell destruction, as calculated by the nitrogen excretion. Loeb and his coworkers (3) state that potassium is retained during adrenal insufficiency, yet in only one of the three adrenalectomized dogs in their experiment was there a positive potassium balance. It is to be stressed that when this dog was in a positive potassium balance anorexia was not present. However, when food was refused by this dog, as in the case of the other two dogs, and insufficiency progressed, this animal also developed a negative potassium balance. Another interesting study on potassium balance during adrenal insufficiency was that performed by Harrop and his coworkers (21). These workers maintain that during insufficiency there is a retention of potassium, and after adrenal cortical hormone is administered to the animal the potassium balance becomes negative. Again, when the potassium balance is posi- 
tive in the dog reported by these authors, the animal is consuming close to his normal food intake. However, when the potassium balance is negative, the animal has developed a marked anorexia, in fact complete starvation. Starvation, as Gamble and his coworkers (15) found in their study of a child fasting twenty-four hours, resulted in the excretion of about eight times as much intracellular water, measured by the potassium excretion, as that of extracellular water, measured by the sodium excretion. The changes in the potassium balance ascribed by Harrop et al. (21) to an effect of the withdrawal and the addition of the cortical hormone may be due to the fact that the animal had not yet shown evidence of severe adrenal insufficiency during the short period of hormone deprivation and secondly, the changes observed following the administration of hormone may be due in part to a lag in the return of the appetite and the electrolyte balance to normal. Furthermore, during the period of deprivation of hormone the elevated blood potassium is associated with an elevated blood urea, and thus may be dependent on kidney insufficiency. When hormone is given, the excretion of the large amount of potassium is associated with the fall in blood urea indicating an improved kidney function. This improvement in kidney function which permits excretion of the once retained potassium might depend on extrarenal factors. Swingle and his associates (22) have demonstrated that hormone given to adrenalectomized animals deprived of food and water produces a temporary rise in the blood pressure, a return towards normal of the blood volume, and a lowering of the blood urea. This effect of the hormone may be one aside from its so-called water and salt regulation and may be operative through its ability to combat the shocklike symptoms of adrenal insufficiency.

The apparent difference between the findings of Loeb, Harrop, and their coworkers and those that we present in this paper may be dependent upon the fact that adrenalectomized rats develop anorexia and severe insufficiency with its dehydration more rapidly than do the larger animals (dogs) used by these above-mentioned workers.

It is questionable whether the elevated blood potassium found during adrenal insufficiency by Harrop and his coworkers indicates that a positive potassium balance occurs during this disturbance.
This may be analogous to the situation of calcium in hyperparathyroidism, where an elevated blood calcium exists while the body is actually being depleted of its calcium. Nevertheless, how can the elevated blood potassium be explained? In those instances where a high blood potassium has been reported, it has always been associated with a high blood urea nitrogen. This piling up of urea in the blood, a condition which comes on after insufficiency is moderately advanced, is generally believed to be due to an inadequate supply of water for renal excretion which in turn reduces the kidney blood flow. (The water intake of the animals with adrenal insufficiency is reduced.) Schoenthal and his coworkers (23) found the urea clearance to be greatly reduced in dehydrated infants. All this might indicate that when the blood potassium is elevated in adrenal insufficiency, there is already a functional kidney insufficiency.

Thus it seems likely that with the continued tissue destruction due to dehydration and inanition resulting in an increasing liberation of urea and potassium for excretion, and with the progressively decreasing functional activity of the kidney, also due in part to the dehydration, there exists an adequate explanation for the elevated blood potassium.

The large loss of potassium found in our animals must have occurred prior to this kidney insufficiency.

In support of this hypothesis is the fact that the blood potassium is elevated in certain instances of kidney damage (18). Further substantiation has been produced by Butler (24), who has found the blood serum potassium elevated in dehydration. The high serum potassium was associated with an elevated blood urea and a decreased blood sodium and chlorine, findings similar to those of adrenal insufficiency.

In a small group of adrenalectomized rats where potassium chloride instead of sodium chloride was given in the drinking water, the animals died rapidly. This apparent toxic effect of potassium on the adrenalectomized rats may be due either to its dehydrating action resulting in a further diuresis or possibly to an ill effect of the high blood potassium on some organ or physiological mechanism. In fact, both of these processes are probably operative. Furthermore, the suscepti- 
bility of the adrenalectomized animals to various toxins is well established.

Findings strikingly similar to those of adrenal insufficiency have been produced by KerpelFronius (16) in the dehydration of normal rabbits brought about by salt restriction and urea feedings. In the dehydration which he produced by salt-poor feeding (sodium chloride), there occurred a loss of sodium from the body in association with a normal potassium retention. This parallels the findings in mild or early adrenal insufficiency as demonstrated by Harrop et al. (21). In the more severe dehydration, which KerpelFronius produced by feeding urea, the changes were similar to those found by us in the dehydration due to advanced adrenal insufficiency where a negative balance of both sodium and potassium occurs. Since the weight loss (water loss) in the urea experiment greatly exceeded that of the sodium chloride free experiment, it would appear that the severity of salt losses and whether or not potassium is excessively excreted depends upon the degree of dehydration.

\section{Nitrogen metabolism}

From the data presented here it would appear that the negative nitrogen balance seen during adrenal insufficiency in our rats is in a large measure dependent upon the decreased food consumption. In addition, as a result of the dehydration, tissue destruction with its release of nitrogen also occurs. From the experimental data of Loeb, Harrop, and their coworkers $(3,4)$, it is seen that their animals were also in a negative nitrogen balance when they were not consuming much food.

That an animal may be in negative nitrogen balance while his blood urea is elevated is seen from the experiments of McCance (25). The elevated blood urea is a manifestation of two factors, first, excessive tissue breakdown, and second, inadequate urea excretion due to the dehydration with its decreased kidney blood flow and subsequent kidney insufficiency.

It should be stressed that when urea is liberated in excessive amounts from the cells during the tissue destruction in adrenal insufficiency, it is in itself a mechanism for further dehydration through diuresis.

\section{CONCLUSIONS}

Following adrenalectomy there occurs early a marked diuresis associated with decreased consumption of food and water producing dehydration and undernutrition, and resulting in an excessive loss of sodium, potassium, and chlorine, along with the other elements investigated. Sodium and extracellular water are lost first, followed, as insufficiency progresses, by a loss of potassium and intracellular water. It has been demonstrated that the partial starvation (water and food) of adrenal insufficiency alone plays a major rôle in lowering the retentions of these electrolytes and nitrogen during adrenal insufficiency.

There seems to be no definite indication that either sodium or potassium is selectively regulated by the adrenal gland. Instead it would appear that the water and general electrolyte metabolism is affected by this gland. In a broad sense, the function of the adrenal gland cortex regarding this one phase, salt and water regulation, appears to be of an antidiuretic nature, since its removal precipitates a diuresis, the underlying factor for so many of the findings in this deficiency.

The improvement of the adrenalectomized animal after cortical hormone therapy and prior to the restoration of the salt and water imbalance (20), and the failure of salt therapy to be uniformly successful in the adrenalectomized rat suggest the existence of other important functions for the cortical hormone. The ability of the cortical hormone to temporarily raise the blood pressure, lower the elevated blood urea, and restore the blood volume towards normal, when injected into animals with adrenal insufficiency on food and water starvation, as was demonstrated by Swingle and his coworkers (22), might account in part for its beneficial effect on the kidney excretion in the presence of an unchanging intake of water and salt.

The salt imbalances found during adrenal insufficiency are similar to those found in other instances of severe dehydration and starvation.

\section{SUM MARY}

1. Balance studies have been made for sodium, potassium, calcium, magnesium, chlorine, phosphorus, and nitrogen on rats before and after 
adrenalectomy, and also following salt therapy.

2. Balance studies were made for similar elements on rats during partial starvation.

3. Adrenal insufficiency was associated with the loss from the body of all the elements investigated.

4. The salt balances in partial starvation were similar to those occurring during adrenal insuffciency, but of a lesser magnitude.

5. At the same level of food and water intake the losses of sodium, potassium, and chlorine were much larger during adrenal insufficiency than during partial starvation, indicating that the electrolyte losses during adrenal insufficiency are not entirely due to the lowered consumption of food.

6. It is suggested that the cortex of the adrenal gland influences the general electrolyte and water balances, not specifically the sodium or potassium balances.

7. It has been demonstrated that salt treatment is of value but does not completely restore the adrenalectomized rat, which suggests, as others have maintained from different evidence, the existence of other functions for the adrenal cortex.

We wish to express our thanks to Dr. Arthur D. Waltz for his study of the pathological material, and to Miss Dorothy Asher and Mr. Harold Stevens for their technical assistance.

\section{BIBLIOGRAPHY}

1. Marine, D., and Baumann, E. J., Duration of life after suprarenalectomy in cats and attempts to prolong it by injections of solutions containing sodium salts, glucose and glycerol. Am. J. Physiol., 1927, $81,86$.

2. Loeb, Robert F., Chemical changes in the blood in Addison's disease. Science, 1932, 76, 420.

3. Loeb, R. F., Atchley, D. W., Benedict, E. M., and Leland, J., Electrolyte balance studies in adrenalectomized dogs with particular reference to the excretion of sodium. J. Exper. Med., 1933, 57, 775.

4. Harrop, G. A., Soffer, L. J., Ellsworth, R., and Trescher, J. H., Studies on the suprarenal cortex. III. Plasma electrolytes and electrolyte excretion during suprarenal insufficiency in the dog. J. Exper. Med., 1933, 58, 17.

5. Rubin, Mitchell I., and Krick, Elizabeth T., Effect of adrenalectomy on salt metabolism in rats. Proc. Soc. Exper. Biol. and Med., 1933, 31, 228.

6. Tisdall, F. F., and Kramer, B., Methods for the direct quantitative determination of sodium, potassium, calcium, and magnesium in urine and stools. $\mathrm{J}$. Biol. Chem., 1921, 48, 1.
7. Greenberg, D. M., and Mackey, M. A., The determination of magnesium in blood with 8-hydroxyquinoline. J. Biol. Chem., 1932, 96, 419.

8. Butler, A. M., and Tuthill, E., An application of the uranyl zinc acetate method for determination of sodium in biological material. J. Biol. Chem., 1931, 93, 171.

9. Fiske, C. H., Determination of potassium. (Unpublished.)

10. Fiske, C. H., and Subbarow, Y., The colorimetric determination of phosphorus. J. Biol. Chem., 1925, 66, 375.

11. Peters, John P., and Van Slyke, Donald D., Quantitative Clinical Chemistry. Volume II. Methods. Williams and Wilkins Co., Baltimore, 1932, p. 833.

12. Sunderman, F. W., and Williams, $P$., The analysis of chloride in tissues. J. Biol. Chem., 1933, 102, 279.

13. Reference (11), Chapter $X$.

14. Harrop, G. A., Soffer, L. J., Nicholson, W. M., and Strauss, M., Studies on the suprarenal cortex. IV. The effect of sodium salts in sustaining the suprarenalectomized dog. J. Exper. Med., 1935, 61, 839.

15. Gamble, J. L., Ross, S. G., and Tisdall, F. F., The metabolism of fixed base during fasting. J. Biol. Chem., 1923, 57, 633.

16. Kerpel-Fronius, Edmund, Uber die Beziehungen zwischen Salz- und Wasserhaushalt bei experimentellen Wasserverlusten. Ztschr. f. Kinderh., 1935, 57, 489.

17. Kerpel-Fronius, E., and Butler, A. M., Salt and water losses in diuretin diuresis and their relation to serum non-protein nitrogen and electrolyte concentrations. J. Exper. Med., 1935, 61, 157.

18. Peters, J. P., Salt and water metabolism in nephritis. Medicine, 1932, 11, 435.

19. Darrow, D. C., and Yannet, H., The changes in the distribution of body water accompanying increase and decrease in extracellular electrolyte. J. Clin. Invest., 1935, 14, 266.

20. Swingle, W. W., Parkins, W. M., and Taylor, A. R., Revival from insufficiency and maintenance of adrenalectomized dogs with low serum sodium and chloride levels. Proc. Soc. Exper. Biol. and Med., 1936, 34, 75.

21. Harrop, G. A., Nicholson, W. M., Soffer, L. J., and Strauss, M., Extracellular and intracellular water loss during suprarenal insufficiency in the dog. Proc. Soc. Exper. Biol. and Med., 1935, 32, 1312.

22. Swingle, W. W., Pfiffner, J. J., Vars, H. M., and Parkins, W. M., The effect of fluid deprivation and fluid intake upon the revival of dogs from adrenal insufficiency. Am. J. Physiol., 1934, 108, 144.

23. Schoenthal, L., Lurie, D., and Kelly, M., Urea clearance in normal and in dehydrated infants; Renal function in intestinal intoxication. Am. J. Dis. Child., 1933, 45, 41.

24. Butler, Allan M. (Personal communication.)

25. McCance, R. A., Medical problems in mineral metabolism. Lancet, 1936, 1, 823. 